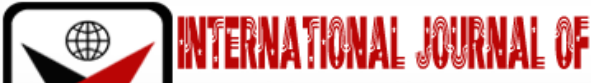 \\ בmRक
}

ISSN 2278-0211 (Online)

\section{Fiscal Policy \& Real Sector Output in Nigeria: 1994- 2019}

\section{Osuji Emmanuel A}

Lecturer, Department of Financial Management Technology, School of Management Technology, Federal University of Technology Owerri

\begin{abstract}
:
This study examined the effect of fiscal policy implementation on the real sector of the Nigerian economy. An econometric model was estimated using the method of ordinary least squares and data were obtained from the Central Bank of Nigeria (CBN's) statistical bulletin for the period 1994-2019. The independent variables were government capital expenditure, government recurrent expenditure, and tax revenue, while the dependent variable was the real sector GDP. The study also tested the null hypotheses that fiscal policy has no significant relationship with real GDP

From our findings, Capital Expenditure did not have a significant relationship with the Nominal GDP of the Real Sector, which means that changes in Capital Expenditure did not contribute significantly in predicting the growth of the real sector. On the other hand, Recurrent Expenditure and Tax Revenue were statistically significant to the real sector GDP. Also, our results show that all the predictor variables were jointly significant at the 0.05 level. Therefore, the study recommended that measures be put in place for a more coordinated approach to fiscal policy implementation and a sustainable plan to limit and control the level of government borrowing in order to avoid undesirable effects that comes with government crowding out the private sector.
\end{abstract}

Keywords: Fiscal policy, real GDP, government capital expenditure, government recurrent expenditure \& taxation

\section{Introduction}

The economy of a nation comprises four interrelated sectors operating to ensure that resources are best utilized in the production of goods and services to maximize the welfare of its citizens. They include the financial sector, the fiscal (government) sector, the external sector and the real sector. While all four sectors play important roles in the economy, the role of the real sector is particularly significant and strategic. The real sector of an economy is where goods and services are produced through the combined utilization of raw materials and other factors of production such as land, labour and capital. It therefore, forms the main driving force of any economy, and the engine of economic growth and development (Sanusi, 2011). The real sector comprises agriculture, manufacturing, construction, etc. The manufacturing, educational, and agricultural sectors are the leading sectors in an emerging economy such as Nigeria (Sanusi, 2011).

\subsection{Problem Statement \& Research Gap}

Apparently, there is disparity between theoretical postulations and empirical findings as regards the effect of fiscal policy on the real sector of the Nigerian economy. While most economic theories are inconclusive on the relationship between fiscal policy and the real sector of the Nigerian economy, some suggest a positive relationship between fiscal policy implementation and real sector output. Some studies also acknowledge the existence of a relationship between the variables but failed to consider capital and recurrent expenditure separately as key components of government spending. Hence, this study is interested in examining the level of significance fiscal policy has on the real sector of the economy, taking into consideration all components and sub-components of both variables.

\subsection{Objectives \& Hypotheses}

The objectives of this study are:

- To examine the impact of government capital expenditure on the real sector of the Nigerian economy.

- To investigate the impact of government recurrent expenditure on the real sector of the Nigerian economy.

- To analyze the impact of taxation on the real sector of the Nigerian economy.

Our study will test the following hypotheses:

- $\mathrm{H}_{11}$ : For Nigeria, capital expenditure and the real sector output has association.

- $\mathrm{H}_{12}$ : For Nigeria, repeated expenditure and the real sector output has association.

- $\mathrm{H}_{13}$ : For Nigeria, taxation and the real sector output has association. 


\section{Literature Review}

\subsection{Conceptual Framework}

\subsubsection{Fiscal Policy}

Fiscal policy simply defined is the use of government revenue through tax system, government expenditure and debt management to achieve pre-determined macro-economic objectives (KayodeAsaju et al, 2014). However, Bhatia (2008) noted that fiscal policy consists of steps and measures which the government takes both on the revenue and expenditure sides of its budget and its aggregate effects on income, production, employment, and other macroeconomic sustenance and growth variables in an economy while Dwivedi (2009) stated that it is government's programme of taxation, expenditure and other financial operations to achieve certain national goals. Buhari (1993) argued that fiscal policy is concerned with deliberate actions which the government of a country take in the area spending money and or levying taxes with the objective of influencing macroeconomic variables such as the level of national income or output, the employment level, aggregate demand level, the general level of prices etc. in a desired direction. Ijeh (2008) refer to fiscal policy as government action plan concerning how to raise funds and disburse funds. He further posited that it is the use of government revenue and expenditure as tools to affect the economy in a way to produce desirable effect such as achieving full employment, general good price level, aggregate demand and economic growth and development.

In general, the term fiscal policy has conventionally been associated with the use of taxation and public expenditure to influence the level of economic activities. Fiscal policy deals with government deliberate actions in spending money and levying taxes with a view to influencing macroeconomic variables in a desired direction. This includes sustainable economic growth, high employment creation and low inflation; thus, fiscal policy aims at stabilizing the economy.

The two main instruments of fiscal policy are government taxation and expenditure. Geoff (2012) contended that fiscal policy involves the use of government spending, taxation and borrowing.

\subsubsection{Fiscal Policy and Economic Growth}

The International Monetary Fund (2009) and CBN (2010) stated that economic growth is the increase in the amount of the goods and services produced in an economy over time. It is conventionally measured as the percent rate of increase in real gross domestic product, or real GDP (RGDP). Growth is usually calculated in real term i.e., inflationadjusted terms, in order to net out the effect of inflation on the price of the goods and services produced. The drivers of economic growth in an economy as posited by Dwivedi (2009) are the quality of the labour force, natural resources, capital formation, technological development and political and social factors while Rena (2011) noted that the determinants are growth in physical capital stock; growth in the size of active labour force available for production; growth in the quality of human capital; technological progress and innovation; institutions including stable democracy, maintaining rule of law and macroeconomic stability; and rising demand for goods and services either led by domestic demand or from external trade. Therefore, for fiscal policy to impact on economic growth, the management of the fiscal instruments will be directed to affect each or some of the drivers of growth as the case may be so as to impact on the overall growth of the economy. The measure and potency of fiscal policy to achieve economic growth will among other things depend on the transparency and accountability of the fiscal institutions, appropriate combination of fiscal strategy and suitable mix of monetary policy, political stability, socio-political inclination of the society, state of nature of the economy and response of the market forces. The practicality of fiscal policy through variations of its instruments to impact on economic growth will depend on the state of nature of the economy at a particular period of time as the management and adaptability of the instruments during each of the state of nature will vary from one period to another. The fiscal policy thrust will be different at each of the economic cycles since at each cycle, the economy will be at different level of equilibrium position. A variation in the fiscal instruments by way of increases in government expenditure through deficit budgeting and reduction in taxes will positively affect aggregate demand, employment, output and income within the economy. This is referred to as expansionary fiscal policy. However, if government desire to reduce aggregate demand, the above measure would be reversed. This is referred to as contractionary fiscal policy. Nevertheless, increase in government expenditures through deficit financing by way of issue of treasury bills, certificates or bonds or tax cut will cause crowding effect of private investments. Jhingan (2009) argued that government can also use discretionary fiscal policy by changing taxes and keeping its expenditure constant, changing its expenditure with constant taxes and vary both expenditure and taxes simultaneously.

\subsubsection{Government Expenditure}

Government expenditure refers to the purchase of goods and services which includes all public consumption, public investment, and transfer payments made by the state (www.Wikipedia.com). Government acquisition of goods and services for current use to directly satisfy individual or collective needs of the members of the community is classed as government final consumption expenditure, while government acquisition of goods and services intended to create future benefits, such as infrastructure investment in transport (roads, railways, etc.), health (water collection and distribution, hospitals, etc.) are classified as government investment (gross fixed capital formation). Transfer payments refer to spending that does not involve transactions of goods and services, but instead represent transfers of money such as social security payments, pensions, and unemployment benefits.

Government expenditure can generally be classified into capital and recurrent expenditure. Capital expenditures are used for creating future benefits; it is incurred when a government spends money on acquisition of fixed assets or 
maintenance of an already existing one (Nteogwuija, 2016) while recurrent expenditure refers to all other payments other than for capital assets which are mostly made in a regular interval of time in an accounting year. Examples include wages and salaries, subsidies and transfers, etc.

\subsubsection{Taxation}

Tax is a compulsory charge imposed by a public authority (Omotoso, 2001). It is a transfer of resources and income (Okpe, 2000) to carry out Govt expenditure (Bhatia, 2008). It helps to achieve stable prices, rapid growth of gross national product and so on (Onoh, 2013). It helps governments to improve the cost of the projects or programmes (Ngerebo and Masa 2012). It helps to raise revenue, to regulate the economy and to control income and employment (Anyanwu ,2002). Proper allocation, distribution can be ensured through budget (Nzotta ,2007). According to Nteogwuija (2016), the distribution function deals with the distribution of income. Nwezeaku (2005) argues that the scope of these functions depends on the political and economic orientation of the people (Nightingale, 2000). Ariwodola (2000) posits that it is accurate to say that the primary objective and purpose of taxation. Tax revenue can also be expended on capital projects (Angahar\& Alfred, 2012). As per Musgrave and Musgrave (2004) it helps to regulate the consumption pattern. In Nigeria, government sometimes introduces tax incentives and attractive tax exemptions as an instrument to woo and induce local and foreign investors (Angahar\& Alfred, 2012). Lekan and Sunday (2006) is said to be the modern objective of Economic community of West African States (ECOWAS). Ola (2004) called taxation is a powerful and potential fiscal stabilizer to induce economic development (Nightingale, 2000).

\subsubsection{Real Sector}

The real sector is the sector responsible for the production and distribution of goods and services (from a combination of factor resources), necessary to meet the consumption demand of an economy. Hence, it drives economic growth and development, provides an indication on the living standard of the citizens of an economy, facilitates the creation of economic linkages with other sectors, helps in capacity building, promotes employment and income generation, and indicates the effectiveness of government's macroeconomic policies (Ezenwa, 2010).

The signals on what to produce and its distribution emanates from two key markets in the sector, namely: (1) the production factor market [i.e., raw material market, labour market, land and capital market] and (2) the output market (i.e., production of agricultural and manufactured goods and general services by business units from factors of production). The key output sectors that make up the real sector are the primary sector (Agriculture \& Mining), the secondary sector (manufacturing and building \& construction) and the tertiary sector (services and commerce) (Adebayo, 2013). The primary sector is engaged in the production and extraction of natural resources (i.e., mining as well as agriculture). It is involved in the production of raw materials, which are either consumed directly or used as input in the manufacturing of other finished goods, the secondary sector comprises manufacturing and industries that processes products of the primary sector into either semi-finished or finished items (i.e. transformation of raw materials into new goods or its components for consumption), as well as construction and building, while the tertiary sector comprises all service activities (i.e. utilities, transport, communication, distributive trade, hotel and restaurant, finance and insurance, real estate and other business services, housing, community, social and personal services as well as government services. In order for the real sector of the economy to optimize these potentials, however, it has to be supported by an efficient financial system. There are ample theoretical and empirical evidence that well-developed financial systems play very crucial and indispensable role in promoting long-run economic growth. Basically, the essence of the financial system is to mobilize and channel financial resources via institutions or intermediaries from the surplus economic units to the deficits units. A well-developed financial system enhances investment by identifying and funding good business opportunities, mobilizing savings, enabling trading, hedging and diversifying risk, and facilitating the exchange of goods and services. These functions result in a more efficient allocation of resources, rapid accumulation of physical and human capital, as well as foster technological progress, which lead to economic growth. Therefore, an efficient financial system is one of the foundations for building sustained economic growth, which can spur employment generation and economic development.

\subsubsection{Initiatives to Grow the Real Sector by the CBN}

Sanusi, (2011), revealed that as part of its developmental role and efforts to boost real sector activities, the CBN has undertaken various initiatives aimed at increasing output, generating employment, diversifying the revenue base of the economy, increasing foreign exchange earnings, and promoting value chain activities in the real sector. In this regard, the CBN through the banking system (Deposit Money Banks) have over the years evolved policies meant to advance credit to the core private sector of the economy, especially the real sector, at the right time and at affordable costs. Some of the financing initiatives include:

\subsection{The Agricultural Credit Guarantee Scheme Fund}

In order to assist banks to aggressively support agriculture, the Agricultural Credit Guarantee Scheme Fund (ACGSF) was introduced in 1978 to guarantee banks' exposure and minimize lending risk. The Scheme is managed by Central Bank of Nigeria (CBN) which provides a guarantee cover to banks who give loans to the agricultural sector of the economy and has an authorized share capital of N3 billion contributed by the Federal Government (60\%) and the CBN (40\%). Potential beneficiaries are requested to provide collateral for loan amounts above N20, 000, while loans below the amount can be guaranteed without collateral. The collateral should be in a tangible form or in form of $25 \%$ cash security of the intended loan amount in the form of savings. As at May, 2011, the sum of N43.86 billion has been guaranteed with respect to 705,361 loans granted to farmers of various categories. 


\subsection{The Trust Fund Model (TFM)}

The Trust Fund Model (TFM) was introduced as a credit guarantee product designed to facilitate and expand the channels of credit purveyance to farmers under the Agricultural Credit Guarantee Scheme (ACGS). The TFM was introduced in 1997 to reinforce the confidence of banks in granting facilities to farmers. Under the TFM, State/Local Governments, Oil Companies and Non-Governmental Organizations (NGOs) are encouraged to support the provision of credit resources by placing funds with banks as part-security to augment farmers' cash savings/securities. When the State Governments and Organizations concede, a tri-partite arrangement comprising the CBN, State Government and the lending bank is put in place in favour of the farmers. Thus, the practicing groups of farmers are encouraged to continue and improve upon their regular savings with the banks.

\subsection{The Interest Drawback Programme (IDP)}

The Interest Drawback Programme (IDP) was introduced in the year 2003 to assist borrowers under the ACGSF reduce their effective borrowing rates without introducing dual interest rate regime or contradicting the existing deregulation policy of the government. Under the IDP, farmers will borrow from lending banks at market-determined rates but the programme will provide interest rebate of a determined percentage to them if the loans are repaid as and when due. Currently, the interest rebate is $40 \%$ of the interest component of all loans fully repaid.

\subsection{The Agricultural Credit Support Scheme (ACSS)}

The ACSS was introduced in 2006 to deepen access to loans for agricultural purposes. Under the Scheme, the beneficiary enjoys a 6.0 per cent rebate on the 14.0 per cent interest rate charged by banks. As at June, 2011, the sum of N19.43 billion has been disbursed by banks with respect to 103 agricultural projects while N844.28 million has been paid out by the CBN as 6.0 per cent interest rebate.

\subsubsection{Budget}

A budget is an instrument stipulating policies and programmes aimed at realizing the development objectives of a government (Obara, 2013). Budgets are basically estimates and serve as avenue through which the government promote economic growth, ensure price stability, create employment, and achieve other fiscal objectives. Hence, on a broader basis, budgets are not only instruments of economic and social policy, but also a planning tool for coordination and an instrument for communication (Asaju, Adagba, and Kajang, 2014). The Nigerian budget consists of the projected revenue and expenditure for a fiscal year. The revenue profile shows the amount and sources of expected revenues for the year in view, while the expenditure profile shows what the expected revenue would be expended on budgeting and its process in Nigeria remain problematic both in the areas of preparation and implementation, hence, the need for adequate control aimed at improving effective resources utilization at the budget implementation stage. Omolehinwa (2003) viewed Budget as the plan of an organization expressed in monetary terms and subject, Meigs and Meigs, (2004) defined budgets as a comprehensive financial plan.

\subsection{Theoretical Framework}

\subsubsection{Keynesian Theory}

Fiscal policy is based on the Keynesian theories of output and employment, which were developed in the midst of the great depression that took place mostly during the 1930s beginning in the United States after a major fall in stock prices that began around September 4, 1929, and became a worldwide affair with the stock market crash of October 29, 1929. During this period, unemployment rates in the U.S and Europe exceeded $25 \%$ and the growth rate of real GDP declined steadily for most of the decade. Keynes and his followers believed that the way to combat the prevailing recessionary climate at that point was not to wait for prices and wages to adjust, but to engage expansionary fiscal policy (increasing government spending and/or decreasing tax rates that causes the government's budget deficit to increase or its budget surplus to decrease)and engage contractionary fiscal policy (a decrease in government expenditure and/or an increase in taxes that causes the government's budget deficit to decrease and it budget surplus to increase) after the economic boom begins, in order to stimulate the economy by boosting aggregate demand and employment.

\subsubsection{Classical \& Neoclassical Theories}

The classical \& neoclassical view is that expansionary or contractionary fiscal policies are unnecessary because there are market mechanisms (as in the free market) which serve to keep the economy at or near the natural level of economic stability at all times. They generally emphasize the crowding out effect of government intervention using expansionary fiscal policy, while Keynesians argue that fiscal policy can still be effective especially in a liquidity trap where, they argue, crowding out is minimal. Their position can be characterized as any increase in government spending necessarily crowds out an equal amount of private spending or investment, and thus has no impact on economic activity. They believe that the government would be 'crowding out' private investment using expansionary fiscal policy in the face of budget deficit, it will demand more loanable funds which would increase interest rates from borrowings. In other words, private companies wanting to finance projects through loans must compete with their government for capital so they offer higher rates of return.

In their view also, expansionary fiscal policy decreases net exports, which has a mitigating effect on national output and income. For instance, when government borrowing increases interest rates, it attracts foreign capital from foreign investors. This is because, all other things being equal, the bonds issued from a country executing expansionary 
fiscal policy now offer a higher rate of return. To purchase bonds originating from a certain country, foreign investors must obtain that country's currency. Therefore, when foreign capital flows into the country undergoing fiscal expansion, demand for that country's currency increases. The increased demand causes that country's currency to appreciate. Once the currency appreciates, goods originating from that country now cost more to foreigners than they did before and foreign goods now cost less than they did before. Consequently, exports decrease and imports increase.

\subsubsection{Government Spending and Tax Multipliers (Fiscal Multipliers).}

The fiscal multiplier is used to determine how much a change in government spending or tax policy increases or decreases an economy's Gross Domestic Product (GDP). The existence of a multiplier effect was initially proposed by Keynes' student Richard Khan. The multiplier effect has been used as an argument for the efficacy of government spending or taxation relief in stimulating aggregate demand in a bid to improve an economy. They believed that fiscal policy can be a powerful lever to move the economy because the effect of an increase in spending or a cut in taxes would be multiplied by stimulating additional demand for consumption goods by households.

The multiplier effect is said to have occurred when a change in spending leads to a much larger change in real GDP (than the initial change) or a ratio of the total change in real GDP caused by a change in taxes. The mechanism that can give rise to a multiplier effect is that an incremental amount of government spending can lead to increased income and hence, increased consumption spending which continues, resulting in an overall increase in national income greater than the initial incremental amount of spending.

The Marginal Propensity to Consume is an important component of the fiscal multiplier. It refers to a percentage of a consumer's disposable income that is used to purchase consumer goods or services. Attahir (2016) in his study, revealed that the fiscal multiplier is given by the equation:

Fiscal Multiplier = 1/ (1-MPC)

For instance, suppose that the Nigerian government pays \#10M to a construction company to have a factory built. The money basically becomes wages to builders, revenue to suppliers, etc. Hence, the builders and suppliers have disposable income, and consumption may rise, increasing aggregate demand and GDP at the same time. Supposing further recipients of the new government spending also spend their new income, this continue to raise aggregate demand and perhaps, give rise to further consumption and so on(I.e.) If the builder receives \#10M and pays out \#8M to perhaps employees (for their services), he has a net income of \#2M which is a corresponding increase in his disposable income; the employees as well experience an increase in disposable income to the tune of \#8M. Assuming an MPC of $80 \%$, these employees save \#1.6M and spend \#6.4M on consumer goods and services. Hence, according to fiscal multiplier theory, the government's \#10M investment has already contributed \#24.4M (\#10M + \#8M + \#6.4M) to the GDP. The process proceeds down the line through every party involved, each experiencing an increase in disposable income. Each participant who experiences an increase in disposable income spends some portion of it on final (consumer) goods according to his or her marginal propensity to consume, which causes the cycle to repeat an arbitrary number of times. Similarly, if government enacted a tax cut, individuals would find themselves with additional disposable income. Their inclination to spend a portion of that additional income would set off a chain reaction of spending increased incomes, and more spending. The key element in this process is that households respond to having additional disposable income by spending at least a part of it on additional consumption which raises aggregate demand, hence GDP.

\subsubsection{Adolph Wagner's Law of Increasing State Activity}

Wagner's law is known as the law of increasing state spending/activity. He first observed it for his country and then for other countries. As per this law, the public expenditure rises constantly along with income.

\subsubsection{The Peacock-Wiseman Hypothesis}

As per this law, the public expenditure depends on revenue collection. A gap is present between the expectations of the people about public expenditure and the tolerance level of taxation. The public expenditure has tendency to increase overtime.

\subsubsection{Theories of Taxation}

According to the cost-of-service theory, the cost incurred by government must collectively be met by the people who are the ultimate receivers of the service (Jhingan, 2009). This theory assumes that there is exchange relationship between tax payers and government (Ahuja, 2012). However, the most popular and commonly accepted theory of taxation is the ability to pay theory. This theory has it that citizens of a country should pay taxes to the government in accordance to their ability to pay. It appears very reasonable and just that taxes should be levied on the basis of the taxable capacity of an individual. Regardless, putting this theory into practice arouses some criticisms as regards the definition of ability to pay. Economists are not unanimous as to what the exact measure of a person's ability to pay.

In order to satisfy the idea of justice in taxation, modern economists are of the opinion that equality of sacrifice can only be achieved if the persons with high incomes are taxed at higher rates and those with low income at lower rates. Hence, they favour progressive system if taxation. This system of taxation however, could result in an increase in the level of tax evasion and avoidance, and as well, discourage investment in an economy. Hence, J. S. Mill and some other classical economists suggested the proportionate principle of taxation where taxes are levied in proportion to the income of individuals and entities, so as to extract equal sacrifice. 


\subsection{Empirical Review}

Fiscal policy is one of the most important tools used by government to achieve macroeconomic stability of the economy of most developing countries. Therefore, the attempt to empirically test the efficacy of monetary and fiscal policy in an economy is of essence. This aspect of the paper has discussed some such previous research works and their empirical conclusions that are related to the study.

Maku (2009) in a study, discovered that both government expenditure and private investment have no significant influence on economic growth in Nigeria, and that the rate of government expenditure to real GDP has been rising since the enactment of the Structural Adjustment Programme (SAP) without contributing significantly to economic growth in Nigeria.

Through an augmented Solow model, (Usman et al. 2011) posited that expenditure on administration, education, transportation and communication has a negative impact on economic growth in the short run, while FDI and expenditure on health and other services have a positive impact on economic growth. However, Usman (2011) used the data period of 1970 to 2008 in his, and the estimation results showed that total capital expenditure, total recurrent expenditure, expenditures on transport and communication, education, and health (HEA), including inflation and overall fiscal balance, are statistically significant in explaining changes in economic growth. However, expenditures on defense (DEF) and agriculture (AGR) are not significant in explaining economic growth.

Also, Loto (2011) investigated the growth effect of sectoral expenditures on economic growth and discovered that expenditures on national security, transportation, and communication were positively related to economic growth, but were not statistically significant. Meanwhile, expenditure on education, though negative, was not significant; expenditure on agriculture was negatively related to economic growth; and expenditure on health was positively related to economic growth.

Again, Peter and Simeon (2011), adopted vector auto regression (VAR) and error correction mechanism techniques to ascertain impact of fiscal policy variables on Nigerian economic growth between 1970 and 2009. Their study revealed that there is a long-run relationship between fiscal policy variables and economic growth in Nigeria.

However, Ogbole et al (2011) made a comparative analysis of the effectiveness of fiscal policy in stimulating economic growth under each of the regulation and deregulation periods of the Nigerian economy. From their findings, they concluded that there is difference in the level of effectiveness of fiscal policy in stimulating economic growth in Nigeria both during regulation and deregulation periods. Abubakar (2016) employed annual data series on selected relevant macroeconomic variables for the period 1981 to 2015 to examine the effect of fiscal policy shocks on output and unemployment in Nigeria using the Structural Vector Auto Regression (SVAR) methodology. Findings of the study showed that shocks to public expenditure have a long-lasting positive effect on output growth and an insignificant positive effect on unemployment in Nigeria.

Nwankwo D. J. (2017) investigated the effect of fiscal policy on economic growth in Nigeria from the period 19702014 using the co-integration Error Correction Model (ECM) approaches. The result of the analysis showed that while government expenditures on its own have no economic impact on economic growth, there exists a long-run relationship between fiscal policy and economic growth in Nigeria. (Abduliah 2000) analyzed the relationship between government expenditure and economic growth and found that the size of government expenditure is very important in determining the performance of the economy. He further advised that, government should not only support and encourage the private sector to accelerate economic growth, but should also increase its budgetary provision on infrastructure, social and economic activities. (Ekpo (1994,) studied the contributions of public expenditure to economic growth in Nigeria over the periods 1960 to 1992. The findings from the study provided support for fiscal policy-led growth through crowd-in private investment resulting from government expenditure basically on infrastructure.

Alex and Ebieri (2014) examined the Impact of fiscal policy on economic growth of Nigeria by employing the Autoregressive Distributed Lag (ARDL) methodology. The study found the evidence of long run equilibrium relationship between fiscal policy and economic growth in Nigeria. Government capital and recurrent expenditure was found to have a significant positive relation on economic growth, while non-oil tax and government total debt were found to have no significant impact on real GDP. However, only capital expenditure was found to have a short run relationship with economic growth.

Nathan (2012) analyzed the impact of fiscal policy on the Nigerian economy by evaluating the causal relationship between money supply, fiscal deficits, exports and economic growth of Nigeria for the period 1970 to 2010 using the error correction methodology; his findings show the presence of a significant relationship between the variables and economic growth. Hence, the study recommended fiscal policy as an effective tool for ensuring economic growth of Nigeria. Obayori (2016) also investigated the effect of fiscal policy on unemployment in Nigeria using the error correction model methodology. Findings of the study revealed that both capital and recurrent expenditure of the government exerted a negative effect on unemployment in Nigeria.

Ogege and Shiro (2012), however, investigated the dynamics of Nigeria's monetary and fiscal policies, focusing specifically on their effects on the growth of Nigerian economy. The paper revealed that both monetary and fiscal policy contributed to the growth of Nigerian economy. Similarly, Sanni, et al (2012) in their research, found that none of the policies can be said to be superior to another; and that a proper mix of the policies may enhance a better economic growth.

The growth of Nigeria over the period 1980-2009 has been observed by Taiwo and Agbatogun (2011). The impact of fiscal policy variables on economic growth in Nigeria has been observed by Medee and Nenbee (2011).

The study employed annual state (and local) data for the years 1947 to 1997 for the 48 contiguous states to estimate the effects of a large number of factors, including taxation and expenditure policies, on state economic growth. The study used orthogonal distance regression (ODR) to deal with the likely presence of measurement error in many of 
the variables. The results indicate that the correlation between state (and state and local) taxation policies is often statistically significant but also quite sensitive to the specific regress or set and time period.

From the empirical reviews above, relating to fiscal policy and economic growth in both Nigeria and other countries, the varying outcome of the findings and conclusions emanates these may be due to differences in methodology, variables used and the period of study. The disparities in these studies present an opportunity to look at this area of research and collect data in order to re-examine the impact of fiscal policy instruments and economic growth.

\section{Data \& Methodology}

\subsection{Data Collection}

The major source of data for this study are publications from the CBN statistical bulletin and the key variables for the study are taxation, recurrent expenditure, capital expenditure and real sector output which were sourced within the period of 1994-2019.

\subsubsection{Model Specification}

In order to answer the research questions and achieve the objectives of this study, we shall employ the Ordinary Least Square (OLS) technique to develop a reliable multiple regression model that shows the relationship between taxation, government capital and recurrent expenditures which are instruments of fiscal policy on the one hand, and Nominal Gross Domestic Product of the Real Sector of the Nigerian economy.

The functional form of our model is:

Real GDP = $\mathrm{f}$ (Taxation, Recurrent Expenditure, Capital Expenditure).

This functional form shows that Real GDP is acting as a response variable while the others act as an independent variable. However, the econometric form of our model is as shown below:

RSNGDP $=\beta_{0+} \beta_{1} \mathrm{GRE}+\beta_{2} \mathrm{GCE}+\beta_{3} \mathrm{TR}+\varepsilon$

Where;

RSNGDP = Real Sector Nominal Gross Domestic Product

$\mathrm{TR}=$ Tax Revenue

GRE = Government Recurrent Expenditure

GCE $=$ Government Capital Expenditure

$\beta_{\mathrm{o}}=$ intercept of the regression, $\beta_{1}, \beta_{2}, \& \beta_{3}$, = model parameters

$\varepsilon=$ the error term.

The hypotheses associated with our research study will be subjected to the t-test and the F-test at 5\% level of significance in order to test the strength of model parameters both individually and jointly.

- Decision Rule: Here, we reject the null hypotheses in each case if the p-values associated with each test statistic for any of the parameters individually or jointly is less than 0.05

\section{Empirical Results}

\subsection{Presentation of Data}

The data employed for this study are hereby presented below:

\begin{tabular}{|c|c|c|c|c|}
\hline YEAR & $\begin{array}{c}\text { RSNGDP } \\
\text { (billions of N) }\end{array}$ & $\begin{array}{c}\text { GRE } \\
\text { (billions of N) }\end{array}$ & $\begin{array}{c}\text { GCE } \\
\text { (billions of N) }\end{array}$ & $\begin{array}{c}\text { TR } \\
\text { (billions of N) }\end{array}$ \\
\hline 1994 & $1,762.81$ & 89.97 & 70.92 & 5.03 \\
\hline 1995 & $2,895.20$ & 127.63 & 121.14 & 6.26 \\
\hline 1996 & $3,779.13$ & 124.49 & 212.93 & 3.56 \\
\hline 1997 & $4,111.64$ & 158.56 & 269.65 & 3.31 \\
\hline 1998 & $4,588.99$ & 178.10 & 309.02 & 10.17 \\
\hline 1999 & $5,307.36$ & 449.66 & 498.03 & 9.56 \\
\hline 2000 & $6,897.48$ & 461.6 & 239.45 & 13.91 \\
\hline 2001 & $8,134.14$ & 579.3 & 438.70 & 20.1 \\
\hline 2002 & $1,1332.25$ & 696.8 & 321.38 & 18.73 \\
\hline 2003 & $1,3301.56$ & 984.3 & 241.69 & 96.2 \\
\hline 2004 & $1,7321.3$ & $1,110.644$ & 351.25 & 87.45 \\
\hline 2005 & $22,269.98$ & $1,321.23$ & 519.47 & 110.37 \\
\hline 2006 & $28,662.47$ & $1,390.102$ & 552.39 & 144.37 \\
\hline 2007 & $32,995.38$ & $1,589.27$ & 759.28 & 198.07 \\
\hline 2008 & $39,157.88$ & $2,117.362$ & 960.89 & 229.32 \\
\hline 2009 & $44,285.56$ & $2,127.966$ & $1,152.80$ & 562.87 \\
\hline 2010 & $54,612.26$ & $3,109.437$ & 883.87 & 649.39 \\
\hline 2011 & $62,980.4$ & $3,314.513$ & 918.55 & \\
\hline
\end{tabular}




\begin{tabular}{|c|c|c|c|c|}
\hline YEAR & $\begin{array}{c}\text { RSNGDP } \\
\text { (billions of N) }\end{array}$ & $\begin{array}{c}\text { GRE } \\
\text { (billions of N) }\end{array}$ & $\begin{array}{c}\text { GCE } \\
\text { (billions of N) }\end{array}$ & $\begin{array}{c}\text { TR } \\
\text { (billions of N) }\end{array}$ \\
\hline 2012 & $71,713.94$ & $3,325.157$ & 874.70 & 710.15 \\
\hline 2013 & $80,092.56$ & $3,214.955$ & $1,108.39$ & 795.61 \\
\hline 2014 & $89,043.62$ & $3,426.941$ & 783.12 & 798.16 \\
\hline 2015 & $94,144.96$ & $3,831.978$ & 818.35 & 778.76 \\
\hline 2016 & $10,1489.5$ & $4,178.595$ & 634.79 & 811 \\
\hline 2017 & $94,892.69$ & $3,812.50$ & 745.42 & 795.97 \\
\hline 2018 & $96,842.38$ & $3,941.02$ & 732.85 & 795.24 \\
\hline 2019 & $97,741.53$ & $3,977.37$ & 704.35 & 800.73 \\
\hline
\end{tabular}

Table 1

Source: CBN Statistical bulletin

\subsubsection{Analysis and Interpretation of Data}

\begin{tabular}{|c|c|c|c|c|c|c|}
\hline \multirow{2}{*}{\multicolumn{2}{|c|}{ Model }} & \multicolumn{2}{|c|}{$\begin{array}{l}\text { Unstandardized } \\
\text { Coefficients }\end{array}$} & $\begin{array}{c}\text { Standardized } \\
\text { Coefficients }\end{array}$ & \multirow[t]{2}{*}{ t } & \multirow[t]{2}{*}{ Sig. } \\
\hline & & B & Std. Error & Beta & & \\
\hline \multirow[t]{4}{*}{1} & (Constant) & 1056.389 & 2521.309 & & .419 & .680 \\
\hline & GRE & 15.189 & 3.696 & .631 & 4.109 & .001 \\
\hline & GCE & -3.327 & 6.354 & -.033 & -.524 & .607 \\
\hline & TR & 40.228 & 13.439 & .392 & 2.993 & .007 \\
\hline \multicolumn{7}{|c|}{ a. Dependent Variable: RSNGDP } \\
\hline
\end{tabular}

Table 2: Coefficients ${ }^{a}$

From our regression coefficients in the above table, the regression equation for Real Sector Nominal Gross Domestic Product can be established thus:

RSNGDP $=1056.388+15.189$ GRE $-3.327 G C E+40.228 \mathrm{TR}$

Hence, from the above regression model, it can be established that a unit increase in Recurrent Expenditure would cause an increase in Real Sector GDP by a factor of 15.189, a unit increase in Capital Expenditure would result in a decrease in Real sector GDP by a factor of 3.327, while a unit increase in Tax Revenue would result in an increase in real Sector GDP by a factor of 40.228. This clearly shows that both Recurrent Expenditure and Tax Revenue have positive relationship with the real sector GDP. On the other hand, there exists a negative relationship between Capital Expenditure and the real sector GDP.

\begin{tabular}{|c|c|c|c|c|}
\hline Model & R & R Square & Adjusted R Square & Std. Error of the Estimate \\
\hline 1 & $.988^{\mathrm{a}}$ & .977 & .973 & 5442.02395 \\
\hline
\end{tabular}

Table 3: Goodness of fit

From Table 3above, the model has a coefficient of determination $\mathrm{R}^{2}$ of $0.977(97.7 \%)$ and an adjusted $\mathrm{R}^{2}$ value of $0.973(97.3 \%)$. This shows that the regression model has a high explanatory power. The values ( $\mathrm{R}^{2}$ and adjusted $\left.\mathrm{R}^{2}\right)$ indicate that over 97 percent of the variations in the dependent variable (Real Sector GDP) are attributable to (and explained by) the explanatory variables (GRE, GCE, TR) in the model. In order words, $97.3 \%$ of the changes that occurred in the dependent variable was explained by the econometric model while $2.7 \%$ is attributable to external, unexplained factors not captured in the model. Therefore, we can safely say that the econometric model developed has a good fit on the data.

\subsubsection{Hypotheses Testing}

\subsubsection{Hypotheses One: GCE}

The t-test is used in the statistical analysis to determine the significance of individual parameter estimates. From the table above, the computed test statistic for GCE is -0.524 while its associated p-value is 0.607 . Since the p-value is greater than the level of significance (0.05), we fail to reject the null hypotheses, thus, the variable in question has an insignificant relationship with the response variable.

\subsubsection{Hypotheses two: GRE}

From the table above, the p-value associated with the test statistic is 0.001 . Therefore, at 0.05 level of significance, we reject the null hypothesis that there is no significant relationship between government recurrent expenditure and the real sector in of the economy. This leads us to the conclusion that there exists a significant relationship between recurrent expenditure and real sector in Nigeria. 


\subsubsection{Hypotheses three: TR}

Similarly, given the test statistic and a p-value of 0.007 , we reject the null hypothesis that no significant relationship exists between taxation and real sector in Nigeria at 0.05 level of significance. This leaves us with the conclusion that a significant relationship exists between taxation in Nigeria, and the real sector of Nigerian economy. Hypotheses four (Test of Joint Significance)

\begin{tabular}{|c|c|c|c|c|c|c|}
\hline \multicolumn{2}{|c|}{ Model } & Sum of Squares & Df & Mean Square & F & Sig. \\
\hline \multirow{3}{*}{1} & Regression & 23860591421.901 & 3 & 7953530473.967 & 268.559 & $.000^{\mathrm{b}}$ \\
\cline { 2 - 7 } & Residual & 562696869.567 & 19 & 29615624.714 & & \\
\cline { 2 - 6 } & Total & 24423288291.467 & 22 & & & \\
\hline \multicolumn{7}{|c|}{ a. Dependent Variable: RSNGDP } \\
\hline \multicolumn{7}{|c|}{ b. Predictors: (Constant), TR, GCE, GRE } \\
\hline
\end{tabular}

Table 4:ANOVA ${ }^{a}$

From the ANOVA table above, the F-value is used to determine the model significance in terms of its adequacy for forecasting and policy analysis. In line with the decision rule, we reject the null hypotheses since the p-value associated with the F- statistic is less than 0.05 . Thus, the explanatory variables jointly explain variations in the dependent variable.

We therefore, conclude that there is a significant relationship existing between fiscal policy and the real sector of the Nigerian economy.

\section{Conclusion and Recommendation}

\subsection{Summary of Findings}

The results of our data analysis show that government recurrent expenditure and tax revenue have a strong positive relationship with real sector output and this is in tandem with established theory and our apriori expectation. The result is also in consonance with the work of Peter \& Simeon (2011), and Nwankwo (2017), who discovered a significant relationship between fiscal policy and economic growth in Nigeria.

However, for some reasons, the recurrent expenditure shows a negative relationship with the response variable and this does not agree with our expectation. However, all the predictor variables jointly have a significant relationship with the predicted variable. Furthermore, the econometric model developed has a good fit on the data with an $\mathrm{R}^{2}$ value of about $97 \%$ which shows that approximately $97 \%$ of variations in the predicted variable is accounted for by the independent variables.

\subsection{Conclusion}

This study shows the dynamism through which fiscal policy implementation affects the real sector of the Nigerian economy. Fiscal policy has been identified as one of the keys means of achieving monetary and financial stability in an economy, as a well-developed financial system has long been recognized to play the role of efficient financial intermediation functions. Given the results of data analysis, the study is of the view that the various economic variables which are part of fiscal policy, collaboratively work in synergy to affect and predict outcomes in the real sector of the Nigerian economy.

\subsection{Recommendations}

Based on our findings, the following are the policy recommendations we recommend:

Those efforts be put in place to establish and sustain effective fiscal policy implementation in the economy in order to boost real economic output.

Also, adequate measures should be put in place by the government to curb the incessant fund misappropriation and diversion, as well as reduce corruption to the barest minimum.

Finally, the government should cut down its level of borrowings from within the economy in order to check the undesirable effects of crowding out the private sector.

\section{References}

i. Abduliah, Y. (2000). Does Government Expenditure inhibit or Promote Economic Growth? Some Empirical Evidence from Saudi Arabia, Indian Economic Journal,48(2): 92-96.

ii. Adebayo O. Oduyemi (2013). Understanding monetary policy series No 33.

iii. Ahuja, H. L. (2012). Modern economics analytical study of microeconomics, macroeconomics, money and banking, public finance, international economics and economics of growth and development (17th ed.). New Delhi:S. Chand \& Company PVT. Ltd.

iv. Alex, E.O., and Ebieri, J. (2014). Empirical analysis of the impact of fiscal policy on economic growth of Nigeria. International Journal of Economics and Finance, 6(6), 48-52.

v. Angahar, P. A. and Alfred, S. I. (2012). Personal income tax administration in Nigeria: challenges and prospects for increased revenue generation from self-employed persons in the society. Global Business and

vi. Economics Research Journal, 1(1): 1-11.

Anyanwu, J.C. (2002). Monetary Economics: Theory, Policy and Institutions. Hybrid Publishers, Onitsha.

vii. Ariwodola, J. A. (2000). Personal taxation in Nigeria, 4th edition. Lagos: JAA Nigeria Ltd. 
viii. Attahir B. A. (2016). Dynamic Effects of Fiscal Policy on Output and Unemployment in Nigeria: An Econometric Investigation. CBN Journal of Applied Statistics Vol. 7 No. 2, 64-66.

ix. Bhatia, H. L. (2008). Public Finance (26th ed.). Jangpura, New Delhi: Vikas Publishing House PVT ltd.

x. Buhari, A. L. (1993). Straight to point ICAN/Polytechnic Public Finance. University of Ilorin, Nigeria: Unillorin press.

xi. Chukwuma\&Obara, (2013). Budget preparation and implementation in the Nigerian Public Sector. Research Journal of Finance and Accounting. 4(2). 50-54.

xii. Central Bank of Nigeria. (2010). Annual report and financial statements. Statistical Bulletin, 21.

xiii. Dornbusch, R, and Fischer, S (1990). Macroeconomics (5th ed.) New York: McGraw-Hill Publishing Company.

xiv. Dwivedi, D. N. (2009). Managerial Economics (7th ed.).Jangpura New Delhi: Vikas Publishing House PVT ltd.

xv. Ekpo, A. (1994). Public expenditure and economic growth in Nigeria 1960 to1992: Final Report. Nairobi: AERC.

xvi. Ezenwa B.K. (2010). Fiscal indicators for economic growth in Nigeria. Nigerian Journal of Economic Development, Research, and Investment, 2(1), 171-183.

xvii. Fadare, S.O. (2010). Recent Banking Sector Reforms and Economic Growth in Nigeria. Middle Eastern Finance and Economics. 6(8), 1450-2889.

xviii. Ijeh S.N (2008). Money and output interaction in Nigeria: An econometric investigation. CBN Economic and Financial Review, 38(5), 222-224.

xix. International Monetary Fund. (2009). Deflation, economic growth, BOP. Celebrating the spirit of small enterprise.

xx. James Nobes (1998): Economics of taxation.

xxi. Jhingam, M. L. (2009). Money, Banking, international trade and Public Finance. Delhi, Nisha Enterprises.

xxii. KayodeAsaju (2014). The efficacy of fiscal policy in promoting economic growth and reducing poverty in Nigeria. Research in World Economy Vol. 5, No. 1; 262-26.

xxiii. Khosravi, A. \&Karimi, M. S. (2010). To Investigate the Relationship between Monetary Policy, Fiscal Policy and Economic Growth in Iran: Autoregressive Distributed Lag Approach to Cointegration. American Journal of Applied Sciences,7(3), 420 - 424.

xxiv. Kothari C.R. (2004). Research Methodology, Methods and Techniques: (second revised edition, new age international production limited, publishers.pp.1-389).

xxv. Lekan, S. \& Sunday, O. (2006). Taxation, Principles and Practice in Nigeria. Ibadan: Silicon Publishing Company

xxvi. Loto, M.A. (2011) Impact of Government Sectoral Expenditure on Economic Growth. Journal of Economics and International Finance, Vol. 3, no.11, pp. 646-652.

xxvii. Maku, O.E. (2009) Does government spending spur economic growth in Nigeria? Munich Personal RePEc Archive (MPRA) Paper No.17941

xxviii. Medee, P.N \&Nembee, S.G (2011). Econometric Analysis of the impact of Fiscal Policy Variables on Nigeria's Economic Growth. International Journal of Economic Development Research and Investment, 2(1), 164 -167.

xxix. Musgrave, R. A. and Musgrave, P. B. (2004). Public finance in theory and practice. New Delhi, India: Tata McGraw Hill.

xxx. Nathan, P.A. (2012). The impact of fiscal policy on the Nigerian economy. International Review of Social Sciences and Humanities, 4(1): 142-150.

xxxi. Ngerebo, T. A., and Masa, A. (2012). Appraisal of tax system in Nigeria: A case of value added tax. Research Journal in Organizational Psychology and Education Studies,1(6): 338-344.

xxxii. Nightingale, K. (2000). Taxation, theory and practice, 3rd edition. London: McGraw Hills Publishers.

xxxiii. Nteogwuija B.N. (2016). Analysis of the impact of fiscal policy on economic growth in Nigeria. European Journal of political Economy, 20(6), 91-124.

xxxiv. Nwankwo D. J (2017). Fiscal Policy-Economic Growth Correlates: Further Evidence from Nigeria Economy. International Journal of Academic Research in Business and Social Sciences, Vol. 7, No. 1, ISSN: 2222-6990

xxxv. Nwezeaku, N.C. (2005): Taxation in Nigeria: Principles and Practice, Owerri: Springfield Publishers.

xxxvi. Nzotta, S. M. (2007). Tax evasion problems in Nigeria: A critique Nigeria account. 12(1): 40- 43.

xxxvii. Obayori, J.B. (2016). Fiscal Policy and Unemployment in Nigeria. The International Journal of Social Sciences and Humanities Invention, 3(2): 1887-1891.

xxxviii. Ogege, S. and Shiro, A. A. (2012). 'The Dynamics of Monetary and Fiscal Policy as a Tool for Economic Growth: Evidence from Nigeria. Journal of Management and Sustainability, 2(2): 247-258.

xxxix. Okpe, I. I. (2000). Personal income tax in Nigeria. Enugu: Ochumba Printing and Publishing Company.

xl. Ola, C. S. (1981). Income tax laws for corporate and unincorporated bodies in Nigeria. Ibadan: Heinemann Educational Books Limited.

xli. Omolehinwa, E. (2003). Government Budgeting in Nigeria. Lagos: PumarkNig Ltd, 1-14

xlii. Omotoso, M. 0. (2001). Principles of taxation. (1st ed.). Ibadan: First Shepherd Investment.

xliii. Onoh, J. K. (2013). Dimensions of Nigerian monetary and fiscal policies- Domestic and external. Aba: Astria Meridian Publishers.

xliv. Peter, N. M. and Simeon, G. N. (2011). Econometric analysis of the impact of fiscal policy variables on Nigeria's economic growth. International Journal of Economic Development Research and Investment, 2(1): 171-183.

xlv. Rena, R. (2011). Public Finance and Taxation. Windhoek centre for lifelong learning, Polytechnic of Nambia

xlvi. Sanni, M. R., Amusa, N. A. and Agbeyangi, B. A. (2012). 'Potency of Monetary and Fiscal Policy Instruments on Economic Activities of Nigeria 1960-2011.Journal of African Macroeconomic Review, 3(1):161-176. 
xlvii. SanusiLamidoSanusi, (2011). Growing Nigeria's real sector for employment and economic development: The role of the central bank of Nigeria.

xlviii. Usman, A., Mobolaji, H. I., Kilishi, A. A., Yaru, M. A. and Yakubu, T.A. (2011) Public Expenditure and Economic Growth in Nigeria. Asian Economic and Financial Review, Vol. 1, no.3, pp. $104-113$. 